\title{
口腔癌急者の細胞性免疫反态に閶する研究
}

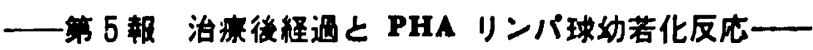

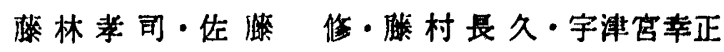 \\ 宫内重幸・綝龍彦・伊藤唀夫
}

\section{Studies on cell-mediated immune responses in oral cancer patients}

\section{PHA-induced lymphocyte tranoformation in clinical courses after treatments}

\author{
Takashi Fujıayashi - Osamu Sato - Nagahisa Fujmura - Yukimasa Utsunomiya \\ Shigeyuki MrYaUch • Tatsuhiko Kon • Hideo ITOH
}

緒

\section{言}

担癌状的における宿主の癌に対する免疫反応の重要性 が近年明らかにされ，癌患者においてる患者の有する細 胞性免疫能が病期や予後と関連することがしばしば報告 されている. 癌患者の細胞性免疫能の評価法としては種 々の方法があるか， PHA による患者末梢血のリンハ球 幼若化反応は非特異的な一般的な細胞性免度能の評価の 目的で, in vitro の方法としては最もよく用いられてい る. 口腔癌患者について，すでにわたくしたちは，PHA によるリンバ球幼若化反応の結果が stage と関連する ことを報告している1).

今回は，同反応と口腔癌患者の治療経過との関係を， 治療後の期間, 治療後の腫瘍の有無による臨床状態, 治 療方法, 死亡例での生存期間などの諸点を中心に検討を 行った.

\section{方}

法

\section{1. 対象症例}

研究対象とした症例は1975年より1978年までの 4 年間 K, 東京医科齿科大学齿学部附属病院第 2 口腔外科で診 察した口腔覀性腫湯患者のららから任意に選択した 80

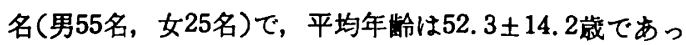
た. 尰場の組織学的分類は, 扁平上皮癌が62例(77.5\%), 腺様瀼胞癌か; 4 例, 悪性黒色腫か; 3 例, 粘表皮癌, 未分 化癌, 悪性リンハ腫が各 2 例, そのほかには骨肉腫, 横

東京医科齿科大学齿学部第 2 口腔外科学教室(主任: 伊藤秀夫教授）

The Second Department of Oral Surgery, Dental Faculty, Tokyo Medical and Dental University (Chief: Prof. Hideo Itoh)

受付日：昭和 54 年 8 月 16 日

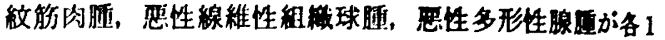

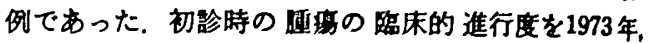

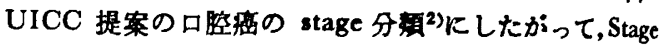
I より Stage Nまで4期に分類した。 この stage 分制

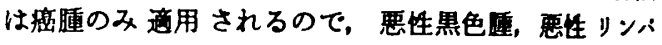

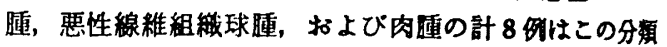
より除外し，残りの 72 例の庭について 分類した結果 は, Stage I 6 例, Stage II 18例, Stage I44 例、お び Stage IV 4 例であった.

治療は 80 例の全例に行われ，外科的手術，故射線治 療，化学瘄法およびその組み合わせが行われた，外科的

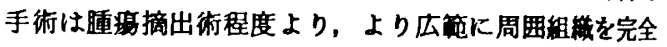
に含めた全切除手術，さらに根本的暊部倣清衍を垪用す るるのなど種々な程度のるのがあるが，これらを外科的 手術として一括した。 このなかには畽䴔の試除切除街は

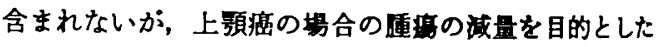
上頻洞開放術は，このなかに含めて分類した。故射線治 療はテレコバルト，ベータトロンによる外部照射をはし め, Au-grain, ラドンシード, ラシシゥム針, コハルト針 などの小線源治療が行われたが, 所定の腫踷線量照射さ れたもののみでなく，術前または術後照射の形で外科的 手術の補助療法として行われた場合も，1,000 rad 以上 照射されたるのについては放射線治療は行われたすのと して分類した，化学療法としては種々の蒋物が用いら れ，抗腫场抗生物質をはしめ Picibanil, Levamisole,

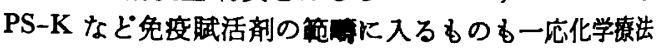
とした。 またその使用量も種々であったが，ごく少量が ごく短期間に投与されたが，なんらかの理由で中止され た場合は除外し，一定量以上がある程度の期間継続的飞 使用されたものを化学療法が行われたすのと判断した。 このよらな一応の基準で分類すると，外科的手街単独群

（S）は 9 例，放射線治療単独群 (R) は 7 例，化学港 法単独群 (C) は 1 例，外科的手術と放射線治寮の甠用 群 (S+R) は 4 例, 外科的手術と化学㙩法の舨用群 
衣 1 時期別にみた PHA によるリンパ球幼若化反応

\begin{tabular}{|c|c|c|c|c|c|c|c|c|}
\hline & \multirow{2}{*}{ 治浓前 } & \multirow{2}{*}{ 治被中 } & \multicolumn{6}{|c|}{ 泊摞 } \\
\hline & & & $2 \mathrm{~W}$ 以内 & $1 \mathrm{M}$ 以内 & $3 \mathrm{M}$ 以内 & 6M以内 & 12M以内 & 12M以上 \\
\hline 症例 数 & 48 & 45 & 46 & 33 & 26 & 19 & 22 & 10 \\
\hline SR 平均 值 & 42.3 & $22.9^{* *}$ & 26. $3^{*}$ & 33.7 & 32.9 & 41.6 & 36.9 & 38.1 \\
\hline SR 標蕇偏差 & 29.1 & 21.2 & 24.4 & 24.6 & 30.4 & 51.2 & 26.2 & 21.6 \\
\hline
\end{tabular}

***治前に比䡈して SR 平均值の低下は有密である $(\mathrm{p}<0.001)$

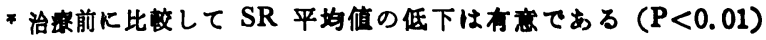

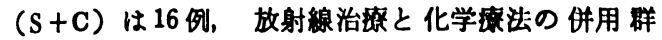
$(\mathrm{R}+\mathrm{C})$ は 21 例，三者併用群 $(S+R+C)$ は22例で あった.

リンバ球纤若化反応の検索時期は，治燎用始前，治療 期間中，治㞠終了後など種々の時期に行ったか，今回は 時間的要因に注目するところから，治意前，治案中，治

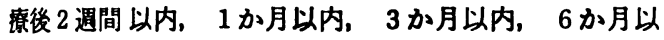
内，12か月以内，12か月以上の 8 時期に分類した。治㞠 前, 中，後を通じた通算検索回数は延べ249例であった.

\section{2. リンハ球の分䑾と培举}

具体的な方法は既報1) と同様であるが，その概要は次 のようである.

被検者の末梢静脈血を少量のへパリン(1000 unit $/ \mathrm{ml})$ を入れた注射器で採取し, Conray-Ficoll 比重遠心法に よりリンバ球を 分離し，細胞数を算定した，培荃液は RPMI 1640 液(日水製薬)に penicillin (100 unit $/ \mathrm{ml}$ ), streptomycin $(100 \mu \mathrm{g} / \mathrm{ml})$, および glutamin ( $2 \mathrm{mM})$ を加え，さらに56 ${ }^{\circ} \mathrm{C} に て 30$ 分非倠化した仔牛胎児血清 Fetal Calf Serum (GIBCO) を最終濃度で10\%になる ように加えたるのを用いた。 リンパ球はこの培養液にて $1 \times 10^{6} / \mathrm{ml}$ の㩐度に調整して, 内径 $12.5 \mathrm{~mm}$, 深さ ! $35 \mathrm{~mm}$ の平底 screw vial (日龟理化硝子, S-1)に $1 \mathrm{ml}$ オ゙つ分注した. mitogen として Phytohemagglutinin-P (Difco, No. 3110-56, 以下 PHA と略す)を Dulbecco's , Phosphate Buffered Saline with $\mathrm{Ca}^{*}, \mathbf{M g}^{*}$ (以下 PBS ，と略す) にて $250 \mu \mathrm{g} / \mathrm{ml}$ の濃度とし、リンパ球浮遊液 $1 \mathrm{ml}$ K対して $100 \mu l$ (PHA $25 \mu \mathrm{g}$ ) を加えた。対照と して PBS を $100 \mu l$ 加えたるのを用いた. 培養は原則 として PHA 添加群, PBS 対照群ともに triplicate で 行い, $37^{\circ} \mathrm{C}$ にて $5 \% \mathrm{CO}_{2}, 95 \%$ air の気相の条件下で 72時間行った。

\section{3. 幼若化反応の測定}

72 時間の培啰 終了 4 時間前に ${ }^{3} \mathrm{H}$-Thymidine ( ${ }^{3} \mathrm{H}$ TdR と略す, New England Nuclear, NET-355) を10 $\mu \mathrm{Ci} / \mathrm{ml}$ K調整したものを $100 \mu l(1 \mu \mathrm{Ci})$ 加えて,さ らに 4 時間培養した. 培食終了後 filter 法 (Millipore filter, HAWP 02500 を使用) で収獲し, リンパ球中に 取り込まれた ${ }^{8} \mathrm{H}-\mathrm{TdR}$ の活性を liquid scintillation

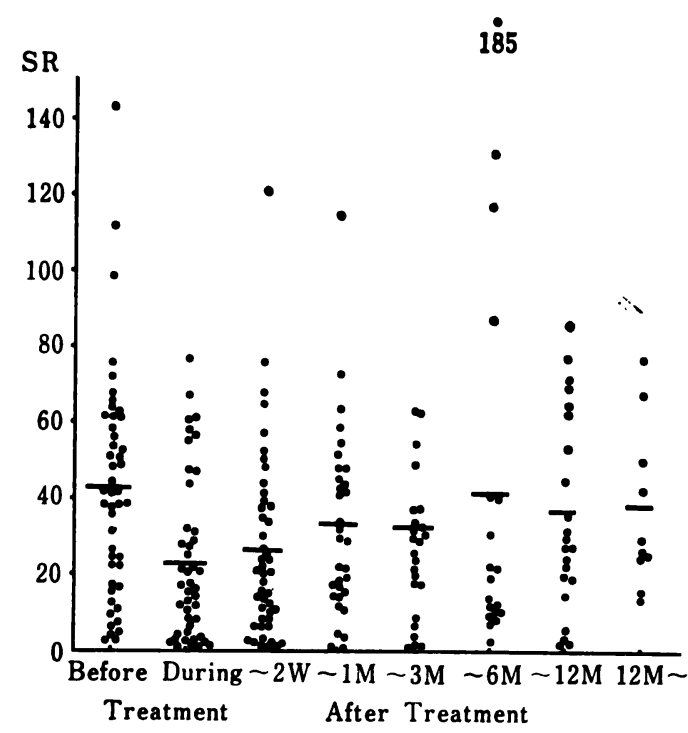

図 1 治症前後の梌案時期別にみたPHAによるリ ソパ球幼若化反応

各点は個々の測定值（SR の値）を示し， 横橉は各時期の平㚬值を示す。

counter (Packard Model 3385) にて湘定した. 测定結 果は count per minute (cpm) で表されるが, リン :球幼若化反応の程度は, PHA 添加培養の cpm の triplicate culture の平均値を, PBS 対照による back ground の cpm の平均値で除算した商で Stimulation Ratio (SR) として表現した.

\section{結果}

\section{1. 時期別にみた検討}

検索した 249 例を検索時期別に 8 時期に分類した場合 の PHA によるリンハ球幼若化反応の結果は, 図1に おのおのの反応值をブロットして図示した. また各群に おける症例数, 反応の平均值および摽準偏差は表 1 に表 示し, 平均値は図1のなかにも横棒で示した. 治療前後 
の各時期を通じて SR の值は比收的幅层い分布を示し， 症例により反応值は多滕性があることを示していたか，

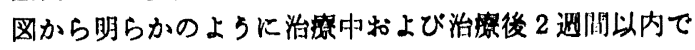
は，比洨的反応低值を示すすのが多く，SR の平均做で

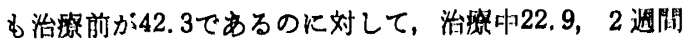
以内26.3と低かった，平均值の差を㭘定すると，治撩中 $(\mathrm{p}<0.001) ， 2$ 週間以内 $(\mathrm{p}<0.01)$ ともに治撩棜に比 校して平均值の低下は有意であった。1か月内，3か 月以内でも $\mathrm{SR}$ の平均値はそれぞれ33.7，32.9 と治楾

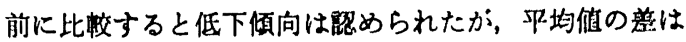
有意ではなかった（ $\mathrm{p}>0.05 ）$. 3か月以降は6か月以 内，12か月以内，12か月以上ともに SR の平均値は注 ぼ治篁前と同様のレベルを示していた。

以上の結果から，治療内容や治療後の臨床状態などを 考虑しないで検索した全症例について考学ると，治療前 の反応平均值に比較して，治療中は明らかに低下し，治 療後 2 週間以内でも低下は有意であるが， 2 週間以後は 次第に反応性は回復し，3か月以降ではほ治療前のレべ ルになることが全般的な傾向であった。

\section{2. 治療後の臨床状慜による模討}

治療後の臨床状態を臨床的にみた聥瘍の有無に注目し て，従来よりわたくしたちが報告しているよらに尚，Ao， Ax, Ac に分類した，すなわち，治療により畽㻛が消失 して肉眼的に腫瘍が喼められないものを Ao, 治療後む 腫湯が明らかに残存していたり，あるいは再発か確琶さ れたものを Ac，検索の時点でそのいずれとも明らかで ないるのを Ax とした。

この分類によれば，治療後 1 か月以内では治療の効果 がいまだ明確でないことが多く，Ax と分類されるるの が多かったが，1か月をすぎると次第に隀㻛の残存の有 無が明らかになって来るので, Ao あるいは Ac と判定 されらることが多くなった。 また，一般に外科的治療で は手術後比較的短期日のらちに腫瘍の残存の有無か明ら かなことが多いが，放射線治療や化学療法では治療終了 後も直ちには腫痬の有無が明らかでないことが多く、し ばしば 1 か月以上や時には3か月以上を経てもAx と判 断されることがあった。治療後 2 週間以内上り12か月以 上まで全期間を通して検索例をこの 分類でまとめて， Ao, Ax, Ac の各群別にリンバ球幼若化反応の SR の 值をプロットしたすのが图2である.

全般的にみると，Ao では高く，Ac では低く，Ax は その中間的な分布の傾向であった。各群の SR の平均 值および標準偏差は横棒で四中に示したが, Ao が 42.4

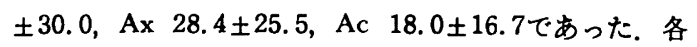
群間で平均値の差の検定を行うと, Ao の平均値の高値 は Ax との比較でも $(\mathrm{p}<0.01), A c$ との比較でも $(\mathrm{p}<0.0005)$ 有意であり，また Ac の低值は Ax との 比較でも有意であった $(\mathrm{p}<0.05)$. つまりこれら 3 群間 にはいずれの間にも有意差が認められた。この結果は,

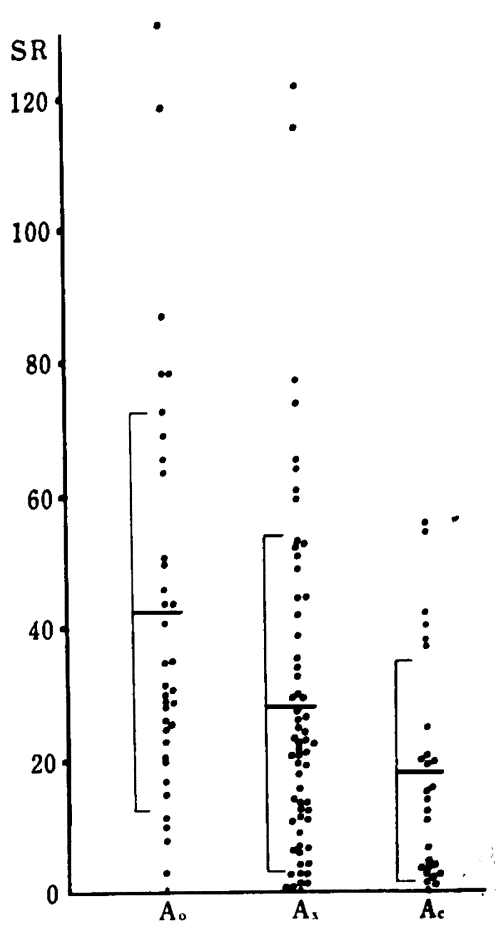

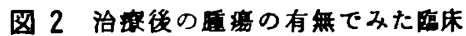
状憵別の PHA Kよるッンパ球 幼若化反底（治接後の全期間）

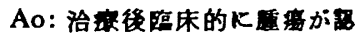
められないるの.Ac: 治晅得明 らかに盾清が存ちるいは再発 しているるの.Ax: 検索の時点 で Ao ともAc とも明らかて ないるの

わたくしたちがすでに報告りしている結果と同様のすの である。

さらに，これを治㞠後の各時期別に検討すると，2速 間以内では，検索症例数は Ao 2 例, Ax 29例, Ac 3 例で, SR の平均値はそれぞれ $37.3 \pm 3.4,26.1 \pm 24.8$, $7.8 \pm 10.0$ であり, 以下同様に Ao, Ax, Ac の順に記戴 すると，1か月以内では，例数 $2,21 ， 3$, 平均值仕 $44.7 \pm 1.8,33.7 \pm 28.6,28.4 \pm 19.7 ， 3$ か月以内ては 例数 $4,8,10$, 平均値は $60.9 \pm 62.9,21.0 \pm 12.4$, $25.7 \pm 16.6 ， 6$ か月以内では，例数は $8 ， 3 ， 5$ ，平均 值は46.1 $150.3,14.6 \pm 7.5,19.3 \pm 12.3$ であった. 12 か月以内では，Ax はなく，Ao は10例で48.7士26.8て

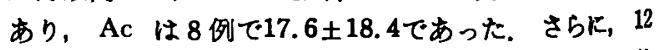
か月以上はすべて Ao で, 症例数10例で，SR の平均值 は38.1土21.6であった。各検索例の SR の值を四示寸 ると複雑になるので，図了では，各時期に打ける A0, $\mathrm{Ax}, \mathrm{Ac}$ それぞれの平均值をプロットし，検索時期によ 


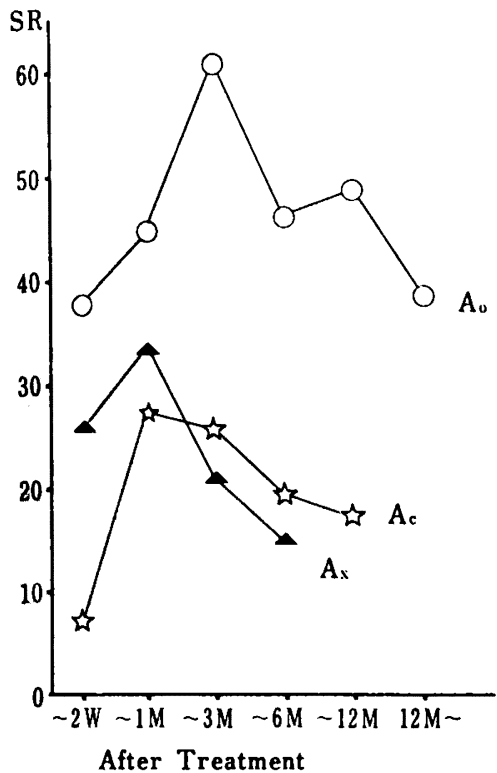

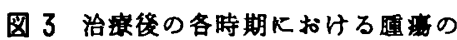
有無による臨床状態別にみた反 底平均値

\section{る変化を折線グラフで示した。}

平均値の差を検定すると，2䓢間以内の Ao と Ac の間 $(\mathrm{p}<0.05)$ ，および12か月以内の Ao と Ac の間 $(\mathrm{p}<0.01)$ には有意差が認められたが，その他の間で は，平均値の差は有意でなかった。 このよらに分類する と，各時期に拈ける各群の症例数が比較的少なくなるの で，平均値の差を検定しても有意差が出にくくなるもの と考えられる。したがって，図にみられる折線クラフの 変化も例数の少ないところもあり，確定的なことはいい 難いか，全体的な傾向としては，治療後の早期より Ao では，すでに SR は比較的高く，Ac では 2 週間以内 で極めて低値を示しており，2 週間以後 1 か月以内で治

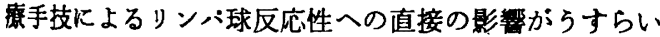
で来るためか， 3 群ともに SR 值は上昇しているが， その後，Ax および Ac 群ではいずれす順次低下傾向を 示した。

\section{3. 治癔法による検討}

治㾘方法によって，治療中および治㞠後のリンパ球奻 若化反応が゚ように左右されるか検討した，治㞠法別 に治㞠中および治療後の反応值をすべてまとめた結果は 图4に示した，各治療法別の検索例数，SR の平均值お よび標準偏差は，それぞれ S が39例，30.9土18.4，Rが

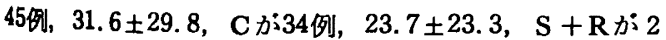
例，23.3土26.9, $\mathrm{S}+\mathrm{C} か 30$ 例, $31.7 \pm 36.4, \mathrm{R}+\mathrm{C}$; 37例， $32.9 \pm 30.3 ＼mathrm{~ お よ ひ ゙ ~} \mathrm{~S}+\mathrm{R}+\mathrm{C}$ か 11 例, $43.6 \pm$

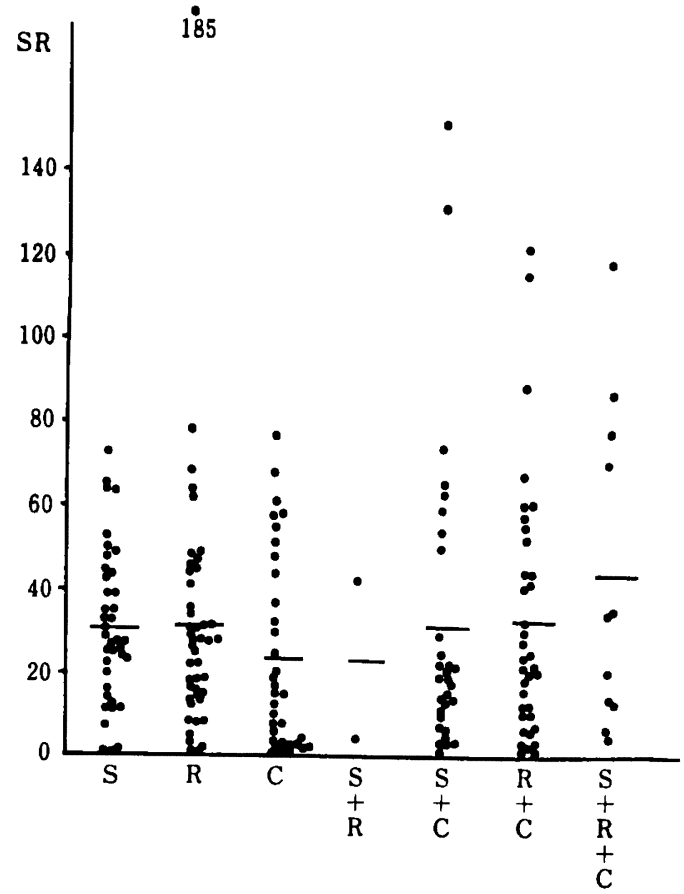

图 4 治法別にみた治後の PHA によるリンハ 球幼若化反店（治症中および治撩後の全期間 のまとめ)

$\mathbf{S}$ : 外科的手征. $\mathbf{R}:$ 故射線洽療. $\mathbf{C}$ : 化 学瘦法. 横棒は各群の反応平均値。

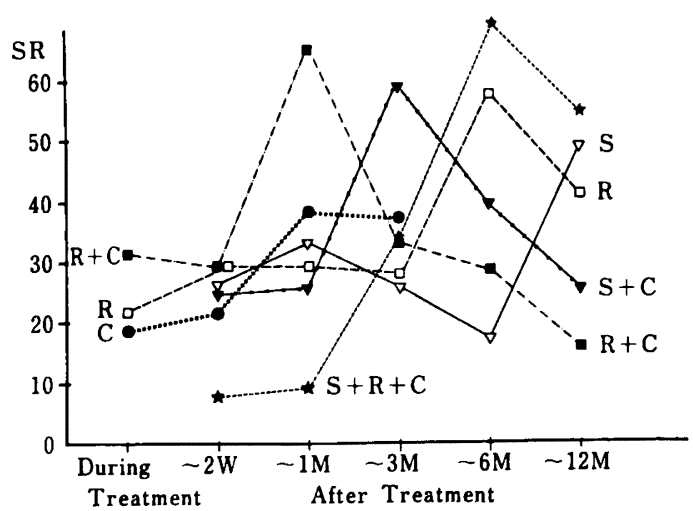

図 5 治掼法別の治療後期間に上る反応平均值の推 移

38.4であった． $\mathrm{S}+\mathrm{R}$ は例数が 2 例で，他は10例以上の 検索例があったか，全般的な所見としては治療法別にみ た SR の平均値にはあまり大きな差はみられず，平均 值の差の検定では, $\mathbf{C}$; $\mathbf{S}+\mathbf{R}+\mathbf{C}$ に比較すると反応の 低下が有意 $(\mathrm{p}<0.05)$ であったが，そのほかにはどの 


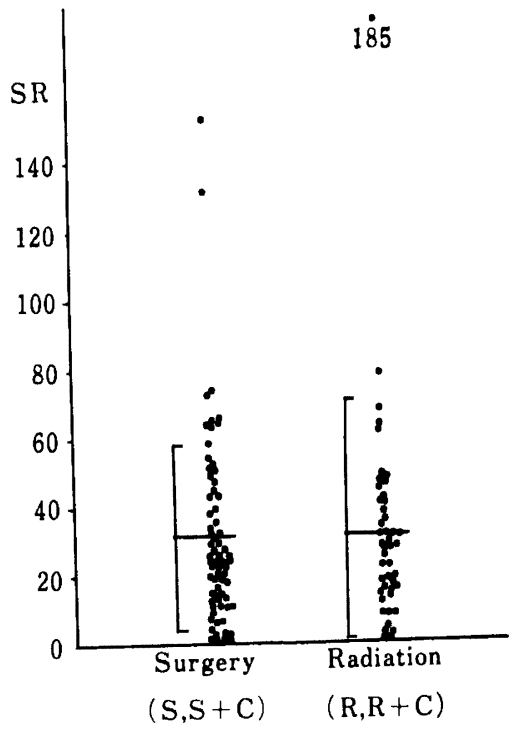

图 6 外科的手吏主体群と放射線洽症 主体群でみた洽症後の PHA に よるリンパ球幼若化反応（治瘄 後全期間）

横棒は反応平均値および標集 偏差を示す。

群の間にも有意差はみられなかった。

次に，これを各時期別に分けて，各治療群の SR の 平均值の推移をみたるのが图 5 である。外科的手術は 1 日で完了寸るので， Sを含む治㞠群では治療中に検索さ れたものはない，各時期に拈ける検索例が治療法により 細分されるので，各群に拈ける症例数は少なくなってい る. 各群で 1 例しかないものは図から除外し，12か月以 後む症例が $\mathrm{S} に$ 片寄るので除いた. 全体的にみると各治 療群とも時期によりかなりの変動を示し, 一定の傾向を 示さなかった．図の各時期での各群の症例数は最も多い わので18例，少ないもので 2 例で，例数の関係で有意差 を検定するにはあまり意味をるたないかとす思われる が，平均值の差の検定を一応行らと，図の中で5\%の有 意水準で差が認められたのは 1 か月以内の $\mathbf{R}+\mathbf{C}$ と + $\mathrm{R}+\mathrm{C}$ の間, 12 か月以内の $\mathrm{R}+\mathrm{C}$ と $\mathrm{S}+\mathrm{R}+\mathrm{C}, \mathrm{S}, \mathrm{R}$ との間の合計 4 群の間のみで，そのほかにはいずれも有

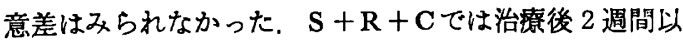
内，1 か月以内では SR は低く，3か月以後は高くな る傾向を示したので，1か月以内は三者併用療法による 治療の影響がリンパ球反応性に抑制的に作用し， 3 か月 以後は治療による直接の影響がなくなり，臨床状態は全 例 Ao であったので, リンハ球反応性が回復し，高い 反応を示したと解釈することも一応可能であると思われ る. しかし，この群の各時期とも症例数は $2 \sim 3$ 例ずつ

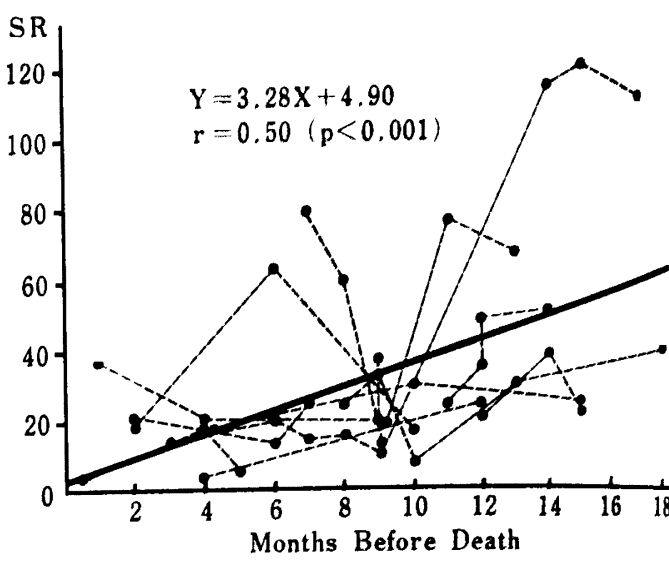

图 7 死亡例での死亡までの生存期間とPHA Kよ るリンパ球幼若化反心との相阘阘保

なのでこの結果のみから上述の解略を磼定することが できないよらに思われる。次いで，各時期における澌定 值を $\mathrm{S}, \mathrm{R}, \mathrm{C}$ の単独治療群と, $\mathrm{S}+\mathrm{R}, \mathrm{S}+\mathrm{C}, \mathrm{R}+$ $\mathbf{C}, \mathbf{S}+\mathbf{R}+\mathbf{C}$ の併用治噔群に分けて, 両者の間に差か あるかを検定したか，いずれの時期においてる，雨群の 間に有意差を認めることはできなかった（p>0.05）.

さらに，外科的手術と放射線治療とを比較する意味か ら， S および $\mathbf{S}+\mathbf{C}$ 外科的手術 (surgery) 主体群, R

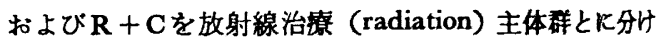
て検討した。 その結果は各時期とる両群の間には有意 差は諗められず（p>0.05）, 治療後の各時期をすへてま とめても图 6 のことくで, 外科的手術主体群が泟例数 $69, \mathrm{SR}$ の平均値 $31.2 \pm 27.5$ に対しして, 故射線治滰主 体群が症例数 $45, \mathrm{SR}$ の平均値31.6土29.8 両群の間に は，はとんどまったく差がみられなかった。

以上の結果を総合すると，治療中および治療後のリン ハ球幼若化反応は治療法の種類にはあまり関係を示す傎 向はなかったといらことができる.

\section{4. 死亡例での生存期間とリンパ球反応性の関係}

死亡した症例について，治㞠後のリンハ球反応性を模 索時から死亡時までの生存期間との関係で分析した。対 象としたのは死亡例中治療後 2 回以上検索した 12 患者 で, 延べ検索数は44例であった，組織型は扁平上皮癌 9 例，悪性黑色腫 2 例，未分化癌 1 例であり，このらち虞 腫10例の治㞠前の stage 分類は, Stage II 2 例, Stage II 5 例, Stage IV 3 例であった. その結果は図7に示し たが，各患者の死亡時よりさかのぼって検査時より死亡 時までの生存期間を月数で横軸にとり，PHA 反応性を SR の值で縦軸にとり，同一患者の各時期の反応性を点 線でつないでその経過を示した，庭例により多少の変動 はみられるが，全体的にみると死亡時期が近つくにした がって，反応性は次第に低下しており，死亡までの生存 
月数 $\mathrm{X}$ と， SR で示した PHA 反応性 $\mathrm{Y}$ との間の相网 分析を行らと，回帰式は図の太い実線で示したごとく， $Y=3.28 \mathrm{X}+4.90$ となり，単回兴分析の結果回为式は有 意水逴 $1 \%$ で成立した。 また相関係数 $\mathbf{2}$ の結果相関係数は有意であった $(p<0.001)$.

すなわち，死亡までの生存期间と PHA によるリン 八球反応性は正の相関を示し，死亡時期が近つくにした がって，PHA 反応性は低下することを示していた。

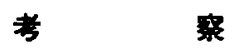

口腔癌患者末梢血リソバ球の PHA 反応性について，

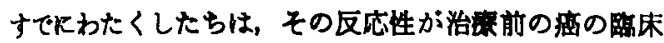
的進行度と相関していることを瑟め，また治接啳の反応 性についてる臨床経過と関連を有することを䟖め，その 一部を報告している゙．今回は，さらに治被後の時間的

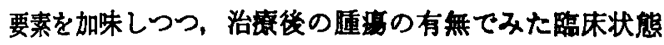

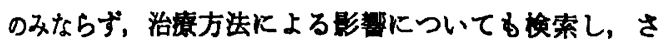
らに死亡例については死亡までの個々の症例の PHA 反 応性の推移を検討した。

癌患者の治療後の PHA に対するリンパ球反応性に ついてはいくつかの報告があり，これを治㞠後の時間で みると，外科的治療啳 2 週間で治寮前よりわずかに反応

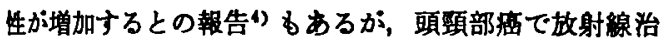
療終了の時点で治療前の約 $50 \%$ 程度に低下5)，外科的治 療で術後 2 週間までは低下6)，肺癌の放射線治療で治滰 中低下し，終了後 4 週間です低下7)，放射線治療後 1 か 月で低下，2４か月でやや回復するが，5１0か月後 です治療前より低下しているら゙など，治療後ある程度の 時期は治療前より低下するとの報告が多い，今回のわた くしたちの検索でも，反応の平均值は治療中および治寮 终了後 2 週間以内は治㞠前に比較して有意に低下してお ク，1か月以内および3か月以内でも低下傾向があった が，3か月以後はほほ治㞠前の反応レベルまで回復を示 した.

治漅後の腫煬の有無でみた臨床状態と PHA 反応性 との関保では, Watkins ${ }^{8)}$ は, 種々の癌患者36例につい て, 外科的手術の前と術後 6 週間での PHA 反応性を検 討し，手術により完全に腫湟が切除された症例の術後の 反応性治潦前より上昇し，健康人対照群と同程度まで 回復するか，腫檺が残存した症例では治療前の低値が回 復せず，対照群より有意に低く，治澺切除群に比してる 有意に低下していたと報告している．折田6) る外科的手 郝後いったん低下した反応性が徐々に回復するが，再発 剐では臨床的に再発が確認される 2 〜 か月前にそれま で回復上界してきた反応性が低下すると述べている．今 回のわたくしたちの結果です，治療後の全期間をまとめ ると，反応平均值は Ao で高く，Ac では低く，Ax で はその中間で 3 群の差は有意であった，各時期別にみる
と，症例数が少なくなり，各時胡で必ずしも有恙盖はみ

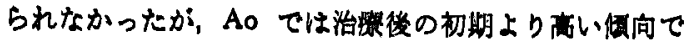

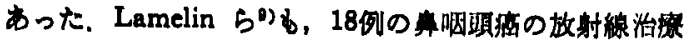

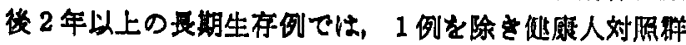
の上限なみの良好な反応性を示したと蚑告している。

このような治素後のリンハ球の PHA 反応性は,一般に

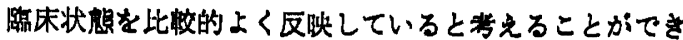
๖. ところか;, Chretien らの NIH クルーブは, リン ハ球の PHA 反応性が瘐の組橡型によって左右される ことを主张し，特に扁平上皮痁については，治虔前より

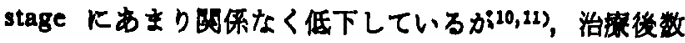

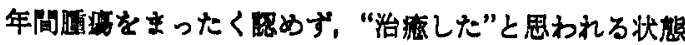

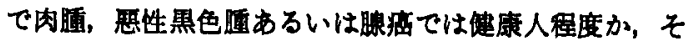
れ以上に回得することが多い12)か，扁平上皮㾜では低下 したまま綂いている症例が多い12,18)という。この点でわ たくしたちの検案では，扁平上皮涪以外の他の組織型の 德性渪晹は例数が十分でなく，組織型別の梌討は行わな かったが，今後さらに組䄳型別の梌索や口腔以外の他部 位の悪性連悬患者を含めた検討が望ましいと思われる。

治療方法の種類が治港後の患者末梢血リンパ球の PHA 反忘性に与える影擎について，今回の検案では外 科的手術，放射線治虔，化学療法およびそれらの組み听 わせに分類して検討したか，治潦方法による明らかな差 異は認めることができなかった，今回の検索は retrospective に行ったるのて，治療の当初より治亦方法によ る差異をみるため各群の対象がなるべく均一な条件にな るよらに振り分けたものではないので，必ずしす同一条 件で比較することはできないと思われる，しかし，当然 のことながら，各症例の治療に際しては畽痽の進行度中 組織型，年龄や合併症の有無などの全身状熊，患者や家 族の希望や治療に対する承諾など，種々の年件を考虑し て最良と思われる治療法が選択されるので, 各治療法の 群において種々の条件を均一にすることは夷際上困難で ある.放射線治療は免疫機能の低下をきたすことが一般 に考えられる.肺瘦の放射線治潦後PHA反応性が低下す ることが報告7 され，頭頸部癌についてす Jenkins らら) によれば, 放射線治寮直後に mitogen に対するリンハ 球反応性は低下しており，1か月後ではさらに低下し， 2４か月後にやや回復傾向を示すか，8～10か月後です 治療前より低下していると報告し, Tarpley 514) 喉頭 咽頭癌で鎖骨より上部の頭頸部に照射された場合です， 治寮後 4 15年, 平均 9 年後の検索で, PHA 反応性は低 下していることから，胸腺や主要な骨髄など主要免疫茂 器に直接照射されたような場合以外でも，長期の免疫抑 制作用があるのではないかと述べている.ささらに Chan ら た患者で, 現在腫湯のない症例でも，治療前と同程度ま で低下しているという，ところが同じ鼻㸶頭癌の放射線 治療について, 治療後 2 年以内は PHA 反応性は低下 


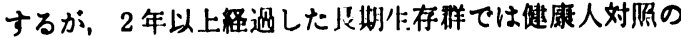

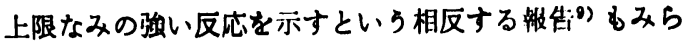

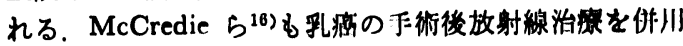
した場合には，手術羿独群に比べて PHA 反応性が約 50\%程度上昇ナることから，局所の放射線治㽷が必ずし も個体の細胞性免疫能を低下させるとはいえないとた張 している.

外科的手術群と放射線治療群を比洨すると，健康人対 照に比し外科的手衍群では有意差がないが，放射線治庩 では外科的手術群に対しても，また対照群に比しても低 下しているとの報告14むみられるか， Silverman ら ${ }^{18) は ~}$ 両群の間に平均做で差がないと跟告しており，わたくし たちの今回の結果す各時期に分けても明らかな善の一定 傾向はみられず，治療後の全模索例をまとめてす両群の 反応平均值はほとんど等しく，有意差がみられなかっ た。 また単独治㞠群と併用治赦群に分けても有意差はな かった.

以上より, 今回の検討の結果からは, 治療後の末梢血 リンハ:球の PHA に対する反応性は用いられた治㞠法 の種類にはあまり関係せず，治療後の時間的要因や腫瘦 の有無による臨床状態の方がより大きく関与していると 思われる。

死亡例におけるリンパ球幼若化反応の検討から, 死亡 までの生存月数と SR で表したリンパ球反応性との間 には有意の相関が認められ，一般に死亡時期が近つくに したがって，リンパ球反応性は低下を示した．菊地 ${ }^{17)}$ す, 症例数は少ないか; 術後生存月数 ( $\mathbf{x}$ ) とリンパ球 幼若化の百分率 $(y)$ との間に $\mathrm{y}=0.61 \mathrm{x}+3.2$ の回帰 式が成立し，相関係数 $\mathrm{r}$ は0.61で， $\mathrm{x}$ と $\mathrm{y}$ の間に有意の 相関（p<0.01）があることを示している. 今回のわた くしたちの検索例は，12患者の44例で，症例によりばら つきも認められるが，今後不幸にして死の転帰をとる症 例をさらに検索すれば，回帰式はより確かなるのになる と思われ，治療後のリンハ球反応性を検索することによ り, 個々の症例の予後の予想や生存期間の推測にも応用 することがある程度可能になるかもしれないと考えられ る.

\section{結論}

口腔癌患者 80 名の末梢血 ソンハ球の PHA による幼 若化反応を延べ 249 例について検索し，その反応性と治 療後経過との関係を, 治療後の期間, 治療後の腫斿の有 無による臨床状態 (Ao, Ax, Ac), 治療方法, 死亡例で の生存期間などの諸点を中心に分析した結果, 次のごと き結論が得られた。

1）治療後の期間でみた反応の平均值は，治療中およ び治療後 2 週間以内は治療前より有意に低下するが，治 療後 1 か月以内および 3 か月以内では治療前より低下傾

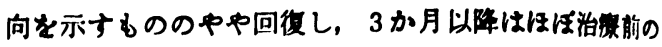
レペルまで回復を示した。

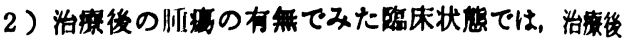
の全期间をまとめると，反心平均值は Ao で高く，Ac では低く，Ax ではその中閌で，3 群の間に有意差が められた。

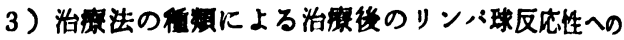

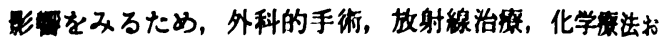
よびそれらの組み合わせに分禹して愉討したが，治港法 による明らかな盖はみられなかった，外科的手街主体群 と放射線治基主体群に分けてる両者の间に有意差はるら れナ゙，巣独象法と併用察法とを比較してる有意差はなか った.

4 ) 死亡例について死亡までの生存月数とリンハ球反 応性とは相阙があ，死亡時胡が近つくにしたがって， 反応性は低下することを示していた。

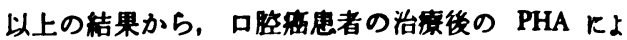
るリンパ球幼若化反応でみた一般的細胞性兔度能は，治 療法の種類にはあまり闺係なく，主として治察後の時间 的要因や腫渴の有無でみた郜床状䈍によって左右される あのと考えられた。

本詥文の要旨は，1979年 4 月，第33回日本口空科学会 総会において器表した。また，本研究の一部は文部省科 学研究費および特定研究费の助成によったことを付記 し, 毇意を表する。

\section{引用文赫}

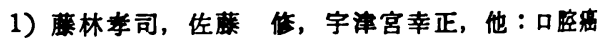

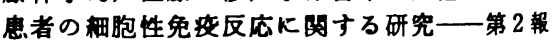
PHA によるリンパ球若化反応. 日外菬 23: 2271977.

2) UICC International Union Against Cancer: TNM Classification of malignant tumours. ed 2, UICC, Geneva, 1974, p 27.

3）藤林孝司，宮沢晋次，高橋雄三，他：口腔虫患

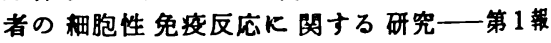
DNCB 反底およひ PPD 反底について。㫜 外誌 22: 6241976.

4）金谷 隆：癌患者における梱胞性免疫能に関す 万研究——第 1 編富患者末梢リンパ球の PHA に上る幼若化現象について，札蜆医誌 43: 481974.

5) Jenkins, V., Ray, P., Ellis, H., et al.: Lymphocyte response in patients with head and neck cancer. Arch Otolaryngol 102: 5961976.

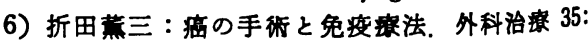
3791976.

7) Thomas, J., Coy, P., Lewis, H., et al.: Effect of therapeutic irradiation on lymphocyte trans- 
formation in lung cancer. Cancer 27: 1046 1971.

8) Watkins, S.: The effects of surgery on lymphocyte transformation in patients with cancer. Clin exp Immunol 14: 691973.

9) Lamelin, J., Ellouz, R., De-Thé, G., et al.: Lymphocyte subpopulations and mitogenic responses in nasopharyngeal carcinoma: Prior to and after radiotherapy. Int J Cancer 20: 7231977.

10) Chretien, P. \& Ketcham, A.: Seventh national cancer conference proceedings. Lippincott Co, Philadelphia, 1973, p 187.

11) Catalona, W., Sample, W. \& Chretien, P.: Lymphocyte reactivity in cancer patients, correlation with tumor histology and clinical stage. Cancer 31: 651973.

12) Twomey, P., Catalona, W. \& Chretien, P.: Cellular immunity in cured cancer patients. Cancer 33: 4351974.

13) Silverman, N., Alexander, J., Hollinshead,
A., et al.: Correlation of tumor burden with in vitro lymphocyte reactivity and antibodies to herpesvirus tumor-associated antigens in head and neck squamous carcinoma. Cancer 37: 1351976.

14) Tarpley, J., Potvin, C. \& Chretien, P.: Prolonged depression of cellular immunity in cured laryngopharyngeal cancer patients with radiation therapy. Cancer 35: 6381975. treated

15) Chan, S., Chew, T., Goh, E., et al.: Impaired general cell-mediated inmune functions in vivo and in vitro in patients with nasopharyngeal carcinoma. Int J Cancer 18: 1391976.

16) McCredie, J., Inch, W. \& Sutherland, R.: Effect of postoperative radiotherapy on peripheral blood lymphocytes in patients with carcinoma of the breast. Cancer 29: 349 1972.

17）菊地浩吉：隀源免将。Modern Medicine 4：35 1975. 